\title{
48 Hulpmiddelen voor functionele verbanden
}

De in dit hoofdstuk beschreven extra hulpmiddelen en instrumenten maken het aanleggen en verwisselen van verbanden gemakkelijker en verhogen het effect en het draagcomfort.

\section{Kleefspray}

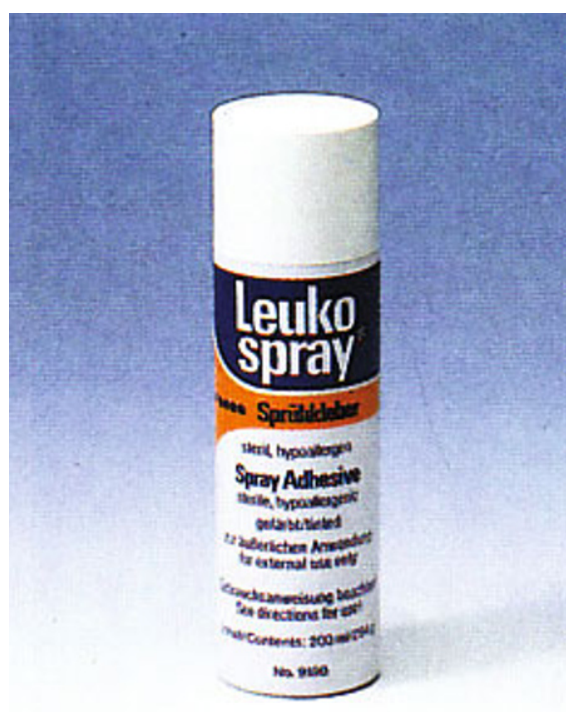

Kleefspray

Functie: huidbescherming, voor behaarde lichaamsdelen die niet worden geschoren (betere hechting); maakt optimale hechting mogelijk tussen huid en onderlaagverband; bij sterke transpiratie.
Huidvriendelijke kleefspray (bijvoorbeeld Leukospray).

\section{Polstermateriaal}

\section{(polstering)}

Functie: opvullen van anatomische holtes (bijvoorbeeld binnen-/buitenkant enkel); polsteren; afvlakken van uitstekende botten; drager voor zalf; extra lokale compressie; bij huidlaesies.

Schuimrubber polsters (Leukotape Foam).

\section{Onderlaagverband}

Functie: beschermen van de gevoelige huid; bij huidlaesies (blaren); bij sterk behaarde lichaamsdelen; bij vochtige huid door transpiratie; voor het fixeren van polstermateriaal, pleisters of vilt; voor extra compressiewerking.

Cohesief fixeerverband (Gazofix, eerst kleefspray op de huid aanbrengen), pleisterverband (bijvoorbeeld Tricoplast).

\section{Afdekverband}

Functie: beschermen van de tape of het verband tegen vervuiling; voorkomen van 'manipulatie' door patiënt of kleding.

Buisverband (bijvoorbeeld Tricofix).

\section{Aanvullende tape}

Functie: bevestigen van verband of tape op mechanisch sterk belaste plaatsen; extra tapestroken ter verbetering van de fixatie bij te los verband of tape (bijvoorbeeld extra pronatiestrook bij het tapen van het enkelgewricht). Niet-elastische tape (Leukotape).

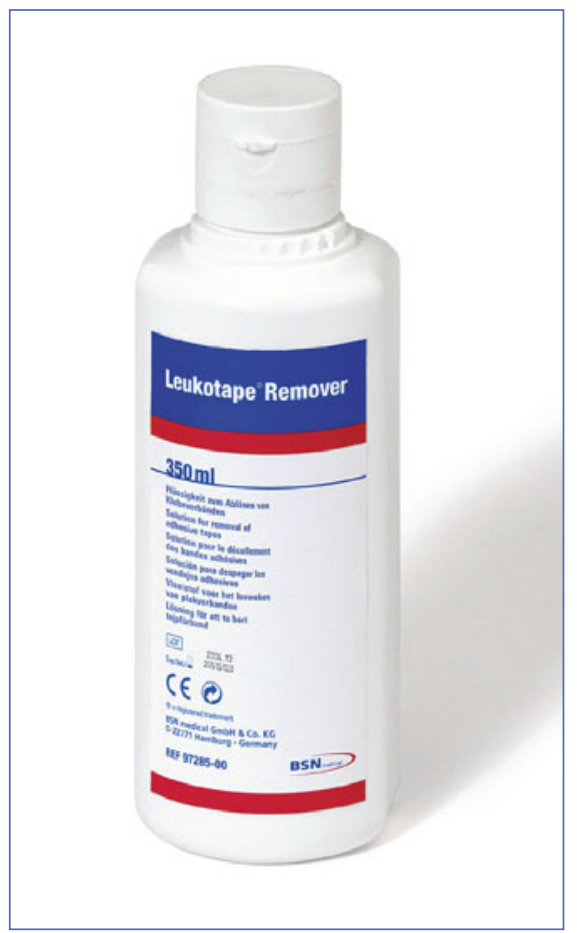

Remover voor het eenvoudig verwijderen van tape 